\title{
ABOLIÇÃO E CIDADANIA: A GUARDA NEGRA DA REDENTORA NO RIO DE JANEIRO
}

\section{ABOLICIÓN Y CIUDADANÍA: LA GUARDIA NEGRA DE LA REDENTORA EN EL RÍO DE JANEIRO}

\begin{abstract}
ABOLITION AND CITIZENSHIP: THE GUARDA NEGRA DA REDENTORA [THE BLACK GUARD OF ISABELLA THE REDEEMER] IN RIO DE JANEIRO
\end{abstract}

\section{ABOLITION ET CITOYENNETÉ : LA GARDE NOIRE « GUARDA NEGRA DA REDENTORA » DE RIO DE JANEIRO}

废除奴隶制和公民权: 里约热内卢的赎罪者黑色卫队

DOI: 10.5533/1984-2503-20135308

Humberto Fernandes Machado ${ }^{1}$

\section{RESUMO}

A historiografia praticamente ignorou a Guarda Negra, associação constituída por libertos que se desenvolveu na fase de agonia do regime monárquico na cidade do Rio de Janeiro, mas que teve repercussão em outras províncias. Ela se desenvolveu em função da ação de grupos urbanos na campanha abolicionista da Corte, na década de 1880, se inserindo no próprio debate entre republicanos e monarquistas, logo após a extinção legal do escravismo. Havia também uma forte rejeição por parte de setores populares, especialmente os libertos, aos defensores da República. Estes acusavam os membros da

${ }^{1}$ Professor do Programa de Pós-graduação em História da Universidade Federal Fluminense.

E-mail: humbertouff@gmail.com 
Guarda Negra de estarem a serviço da monarquia, identificando-os como capoeiras e responsáveis pelos conflitos ocorridos com os republicanos.

Palavras-chave: Guarda Negra, Libertos, Abolicionismo, Imprensa.

\section{RESUMEN}

La historiografía prácticamente ha ignorado la Guardia Negra, asociación constituida por libertos que se ha desarrollado en la fase de agonía del régimen monárquico en la ciudad de Río de Janeiro, pero que ha tenido repercusión en otras provincias. Ella se ha desarrollado en función de la acción de los grupos urbanos en la campaña abolicionista de la Corte, en la década de 1880, se insertando en el propio debate entre republicanos y monarquistas, tras la extinción legal de la esclavitud. Además había un fuerte rechazo por parte de los sectores populares, especialmente los libertos, a los defensores de la República. Estos acusaban los miembros de la Guardia Negra de estar al servicio de la monarquía, los identificando como capoeiras y responsables por los conflictos ocurridos con los republicanos.

Palabras clave: Guardia Negra, Libertos, Abolicionismo, Imprenta.

\section{ABSTRACT}

Historiography has practically ignored the Guarda Negra, an association of emancipated slaves formed during the period of agony experienced by the monarchic regime in the city of Rio de Janeiro, and which also had repercussions in other provinces. The group was developed through initiatives by urban groups in the court's abolitionist campaign during the 1880s, entering into the debate between republicans and monarchists immediately upon the legal prohibition of slavery. A strong rejection of the defenders of the republic also occurred among working-class sectors, especially by those who had been emancipated. These defenders accused members of the Guarda Negra of being at the monarchy's service, branding them as henchmen and as responsible for the conflicts incurred with the republicans.

Key words: Guarda Negra, Emancipated Slaves, Abolitionism, Press.

\section{RÉSUMÉ}


L'historiographie ignore le plus souvent la Garde noire, une organisation d'esclaves libérés qui s'était développée dans la vile de Rio de Janeiro durant la phase d'agonie du régime monarchiste, mais dont les répercussions se firent sentir dans d'autres provinces. La Garde noire s'inscrivit dans la lignée de l'action de groupes urbains dans la campagne abolitionniste de la Cour, dans les années 1880 , et s'invita dans le débat entre républicains et monarchistes qui suivit l'extinction légale de l'esclavage. II existait également un fort rejet des défenseurs de la République de la part des classes populaires, et plus spécialement des esclaves libérés. Les républicains accusaient les membres de la Garde noire d'être au service de la monarchie et la considérait comme un repaire d'hommes de main responsables des conflits avec les républicains.

Mots-clés: Garde noire, Esclaves libérés, Abolitionnisme, Presse.

\section{摘要}

史料学基本上忽略了巴西帝国时代历史上的黑色卫队的存在。这个卫队是一个由自由黑人组 成的, 在君主制最后的痛苦挣扎阶段于巴西帝国首都里约热内卢成立的协会, 它在里约市之 外也有影响。它的发展得益于1880年代巴西帝国朝廷里的废奴运动和城市民众的废奴行动 。它的出现也和当时的政治辩论有关, 在奴隶制已经失去合法性的时候, 巴西人民讨论君主 制和共和制的优劣, 普通民众里有部分人强烈反对共和制, 特别是自由黑人, 他们组织成立 了支持君主制的黑色卫队。共和派谴责黑色卫队是君主制的帮凶，把它描述成卡普诶拉(cap oeiras，一种黑人体育搏斗活动，译者注)，应该对其与共和派产生的冲突负责。

关键字: 黑色卫队, 自由黑人, 废奴主义, 报章媒体

A cidade do Rio de Janeiro, sede da Corte, sempre teve uma grande concentração de população negra desde o século XVIII. Através do seu porto, os traficantes abasteciam a região mineira e, no século XIX, as fazendas cafeeiras do sudeste, em especial do Vale do Paraíba. De acordo com o censo de 1849, o Rio de Janeiro possuía 205.906 habitantes sendo 78.855 , ou seja, $38,3 \%$ cativos, sendo a maior cidade escravista das 
Américas. ${ }^{2}$ Posteriormente, em 1872, o número de escravos reduziu-se a 48.939: 17,8\% de 274.972 habitantes, situação decorrente da paralisação do tráfico e da venda de escravos para as áreas rurais, especialmente a cafeeira, além das altas taxas de mortalidade provocadas pelas epidemias de cólera e febre amarela. ${ }^{3} \mathrm{Em} 1890$, do total de 522.651 habitantes, aproximadamente 180.000 , isto é $34 \%$, eram identificados como negros ou mestiços, 124.119 como estrangeiros, sendo cem mil portugueses. ${ }^{4}$

As contradições da cidade acentuaram-se a partir da década de 1880: a prosperidade derivada das transações comerciais e o uso mais acentuado da mão de obra assalariada, nas manufaturas emergentes, conviviam com os traços inerentes às estruturas arcaicas da velha sociedade colonial apoiada no braço do cativo. $\mathrm{O}$ alemão Carl Von Koseritz (1830-1890) retratou muito bem este quadro, destacando as "novidades" abundantes nas casas comerciais: "[...] vitrinas brilhantes mostram os produtos da indústria europeia e inúmeros artigos de luxo são nelas expostos". Ao mesmo tempo, criticou a existência de escravos que perambulavam pelas "ruas estreitas $e$ sombrias". 5 Assim, os hábitos europeizados das elites da cidade contrastavam com a maciça presença dos escravos.

Esse espaço com inúmeras contradições tornou-se o palco privilegiado da campanha abolicionista. Esta assumiu uma feição particular no Rio de Janeiro em função do seu alto grau de cosmopolitismo e sua identificação com os problemas do país. 0 abolicionismo local caracterizou-se por um maior grau de contestação do que os seus congêneres de outras regiões. Esse contexto favoreceu o surgimento de manifestações de caráter popular, demonstrando a insatisfação contra medidas tomadas pelas elites, desenvolvendo-se uma nova cultura política a partir dos pleitos dos segmentos marginalizados, com ampla divulgação pela imprensa. A oposição dos seus habitantes ao

\footnotetext{
${ }^{2}$ Karasch, Mary C. (2000). A vida dos escravos no Rio de Janeiro (1808-1850), São Paulo: Cia. das Letras, p.109-112.

3 Abreu, Maurício de Almeida (1988). A evolução urbana do Rio de Janeiro. 2. ed., Rio de Janeiro: IplanRio/Zahar, p.54. Chalhoub, Sidney (1990). Visões da liberdade: uma história das últimas décadas da escravidão na Corte, São Paulo: Cia. das Letras, p. 199.

${ }^{4}$ Alencastro, Luiz Felipe (1997). "Vida Privada e Ordem Privada no Império". In Alencastro, Luiz Felipe (Org.) (1997). História da Vida Privada no Brasil: Império, São Paulo: Cia. das Letras, v. 2, p. 25 e segs.

${ }^{5}$ Koseritz, Carl Von (1980). Imagens do Brasil, São Paulo: EDUSP; Belo Horizonte: Itatiaia, p.31. Edmundo, Luiz (1957). O Rio de Janeiro do Meu Tempo. 2. ed., Rio de Janeiro: Conquista. 5 v.
} 
descaso do governo em relação aos seus interesses provocou, inclusive, algumas revoltas populares que marcaram o período e extrapolaram a luta antiescravista, como a Revolta do Vintém, em janeiro de 1880, contra a criação de uma taxa que incidia sobre o transporte urbano. 6

A melhoria do sistema de comunicações e a circulação mais rápida das notícias através dos jornais facilitaram essa mobilização, além do que a imprensa adquiriu um papel relevante na difusão das ideias abolicionistas e republicanas. Os assuntos políticos "ganharam as ruas" junto com os periódicos e os grupos urbanos tiveram maior facilidade para externar as suas reivindicações. Claro está que em uma cidade negra, como o Rio de Janeiro, essas mudanças tinham repercussão, em virtude do número elevado de escravos. Assim, a campanha abolicionista se expandiu com a participação de segmentos populares. Os novos atores políticos estavam ávidos para externarem seus anseios e insatisfações, contidos até então. Nada mais natural em virtude das condições existentes na cidade, onde escravos e libertos conviviam com mulatos e brancos pobres marginalizados pelas elites.

A campanha abolicionista ocupou vários espaços no Rio de Janeiro: do Parlamento às ruas, dos teatros às igrejas e jornais, das casas grandes às próprias senzalas. Esses locais serviam para criticar o que Joaquim Nabuco (1849-1910) denominava a "nefanda instituição". ${ }^{7}$ Festas beneficentes e quermesses também eram organizadas para angariar a simpatia popular e recursos destinados à alforria dos cativos. A ação nas vias públicas como elemento de pressão para convencer os proprietários dos males do cativeiro também era outro artifício usado pelos militantes. ${ }^{8}$

As conferências dos oradores abolicionistas superlotavam os teatros. Por ocasião das comemorações pela extinção legal da escravidão no Ceará, em 1884, o teatro Polytheama, no centro da cidade, foi todo decorado por coroas de flores e bandeiras das

\footnotetext{
${ }^{6}$ Sobre o assunto, ver: Graham, Sandra L. (1991). "O motim do Vintém e a cultura política do Rio de Janeiro em 1880". In Revista Brasileira de História, São Paulo, v. 10, n. 20, p.211-232. Bergstresser, Rebecca B. (1973). The Movement for the Abolition of Slavery in Rio de Janeiro. 1880-1889, Tese (Doutorado em História)-Stanford University.

7 Nabuco, Joaquim (1949). Obras completas de Joaquim Nabuco: O Abolicionismo. Conferências e Discursos Abolicionistas, São Paulo: Progresso Editorial, v. 7.

${ }^{8}$ Machado, Humberto Fernandes (1998). "O Abolicionismo 'ganha as ruas' no Rio de Janeiro". In Revista da Sociedade Brasileira de Pesquisa Histórica, Curitiba, n. 4, p. 71-76.
} 
sociedades abolicionistas do Rio de Janeiro. A leitura de uma carta de Joaquim Nabuco, que estava na Europa, as execuções do Hino Nacional e do Guarani, de Carlos Gomes (1836-1896), marcaram o início de um "verdadeiro carnaval" no centro da cidade, com a participação de dez mil pessoas. As ruas centrais, com destaque para a Rua Uruguaiana, onde se encontrava a redação da Gazeta da Tarde, principal órgão antiescravista da Corte e cujo proprietário era José do Patrocínio (1853-1905), serviram de cenário para as festividades repletas de "alegria e entusiasmo". 9

Apesar das condições desfavoráveis, em função do alto grau de analfabetismo, houve um crescimento da quantidade de leitores e de grupos intelectualizados nas cidades, especialmente no Rio de Janeiro, a partir da década de $1880 .^{10}$ Os jornais conseguiam propagar as "novidades" da época e as ideias contrárias ao cativeiro entre a população alfabetizada. A influência dos periódicos pode ser aquilatada pelas várias manifestações de rua envolvendo jornalistas e pela transformação das próprias redações em locais divulgadores das posições antiescravistas. Assim, a imprensa ajudava a ampliar a opinião pública que não se restringia mais às elites intelectuais, embora a linguagem dos jornais se dirigisse a esse setor. O seu maior envolvimento na campanha abolicionista, "ganhando as ruas", favoreceu um maior engajamento de setores populares. $^{11}$

Os jornais "ganham as ruas" da cidade através de vendedores ambulantes, constituídos por '[...] rapazinhos italianos, negros e mulatos, que nos deixam quase surdos com a sua gritaria [...]" oferecendo os diversos periódicos, como observou Koseritz. ${ }^{12}$ Por outro lado, surgiram também pontos de venda, como quiosques, que os distribuíam juntamente com livros, impressos, flores, doces, charutos, cigarros, pequenas miudezas, café e refrescos. Nesses locais, por onde circulavam as notícias, era comum a

${ }^{9}$ Gazeta da Tarde (1887), 8 de agosto.

${ }^{10}$ Conrad, Robert E. (1978). Os Últimos Anos da Escravatura no Brasil: 1850-1888, Rio de Janeiro: Civilização Brasileira, p.182. Sobre o analfabetismo e a relação entre o autor e o público leitor, consultar: Darnton, Robert (1990). O Beijo de Lamourette. Mídia, Cultura e Revolução, São Paulo: Cia. das Letras, p. 210-212

${ }_{11}$ Machado, H. (1998). Op. Cit., p. 74. Machado, Maria Helena (1994). O Plano e o pânico: os movimentos sociais na década da abolição, Rio de Janeiro: EDUFRJ; São Paulo: EDUSP, p. 162-166. Bergstresser, R. (1973). Op. Cit., p.9-18.

${ }^{12}$ Koseritz (1980). Op. Cit., p. 52-53. 
leitura dos textos em voz alta, sendo que os jornais eram mais ouvidos e vistos do que lidos. A "leitura de ouvido" fazia com que as ideias abolicionistas fossem difundidas mesmo a analfabetos. As pessoas começavam a tomar maior contato com as notícias através da publicidade efetuada pelos próprios jornaleiros, interessados nas vendas. ${ }^{13} \mathrm{~A}$ "questão do elemento servil" tornou-se o assunto principal da pauta dos periódicos.

Mas nem sempre os desdobramentos da campanha eram pacíficos, em especial quando denunciavam as arbitrariedades da estrutura de poder. As atitudes das autoridades governamentais durante o Gabinete Cotegipe (8/1885-3/1888) contribuíram para o aumento da tensão entre os abolicionistas e os que desejavam a preservação do cativeiro. A proibição de "ajuntamentos em praças e ruas" quase provocou um confronto de graves proporções, em agosto de 1887, quando a Confederação Abolicionista do Rio de Janeiro organizou um meeting no Teatro Polytheama. Durante o discurso de Quintino Bocaiúva (1836-1912), explodiram bombas dentro do recinto. Em seguida, entraram "policiais armados de cacetes", que lutaram com os assistentes. Após a expulsão dos policiais para o jardim, o recinto foi invadido por "um piquete de cavalaria e outro de infantaria". Evitou-se o conflito após entendimentos mantidos entre os líderes e as autoridades policiais. Os espectadores foram para a Rua do Ouvidor, protestando contra o governo e aclamando a Confederação Abolicionista. ${ }^{14} \mathrm{~A}$ tentativa de proibição de reuniões públicas não surtia efeito, pela repercussão do abolicionismo nos vários setores da sociedade, inclusive pela resistência do próprio escravo.

Nada mais natural, portanto, que as demonstrações de júbilo ocorridas em vários locais do país pela aprovação da abolição. No Rio de Janeiro, uma multidão aglomerou-se no Paço Imperial e arredores comemorando a assinatura da Lei de 13 de maio de 1888, pela Princesa Isabel. Os jornais da cidade patrocinaram festividades, como missas que reuniram, além da família imperial e do gabinete, uma verdadeira multidão. Procissões, regatas na enseada de Botafogo, corridas de cavalo, teatros franqueados ao público,

\footnotetext{
${ }^{13}$ Machado, H. (1998). Op. Cit, p.74. Goulart, Paulo Cezar Alves (1987). "A venda de jornais no século XIX". In Leitura, São Paulo, v. 5, n. 57. Barbosa, Marialva (2000). Os Donos do Rio. Imprensa, Poder e Público, Rio de Janeiro: Vício de Leitura, p. 200.

${ }_{14}$ Gazeta da Tarde (1887), 8 de agosto. A Confederação Abolicionista, fundada na Corte, em 1883, na redação da Gazeta da Tarde, unificou as diversas associações do Rio de Janeiro como forma de fortalecer a campanha contra o cativeiro.
} 
faziam parte das celebrações pela extinção legal do escravismo. As ruas da cidade foram ornamentadas com bandeiras e flores. Nas sacadas dos sobrados, os panos coloridos retrataram a alegria da população. A mobilização dos setores urbanos contribuiu inquestionavelmente para a derrocada de uma estrutura secular que impedia o país de galgar os degraus do progresso e da civilização.

No entanto, a marginalização dos segmentos mais pobres da população e as circunstâncias adversas, que não possibilitavam o exercício pleno do direito de cidadania, favoreceram a proliferação de grupos que utilizavam expedientes notoriamente considerados escusos para a obtenção de meios para a sua sobrevivência. Esses segmentos despossuídos, nas comemorações festivas pela abolição, elegeram como heróis aquelas figuras com as quais se identificavam, tais como: José do Patrocínio e a Princesa Isabel (1846-1921). O processo de mitificação da Princesa Isabel, com o apoio dos abolicionistas entre os quais Patrocínio e Joaquim Nabuco, provocava a ira dos republicanos que os acusavam de "vendidos" ao Império. Os ataques à monarquia se vinculavam ao pleito de muitos fazendeiros por indenização em virtude do fim oficial do cativeiro, engrossando as hostes republicanas, como última tentativa de conseguirem o atendimento às suas reivindicações - os "Republicanos de 14 de maio" - como Patrocínio os denominava. ${ }^{15}$

As divergências já existentes entre o jornalista e os republicanos, devido à condução do movimento abolicionista, acentuaram-se após a abolição, principalmente pelo apoio de Patrocínio à Guarda Negra. Quintino Bocaiúva (1836-1912), Silva Jardim (1860-1891) e Rui Barbosa (1849-1923) entraram no rol dos seus desafetos, acusados, conforme o jornalista, de defensores dos "republicanos escravocratas". As polêmicas com Rui Barbosa relacionaram-se à questão dos "crimes" efetuados pelos escravos contra os senhores e feitores durante o cativeiro. Rui Barbosa favorável à punição, enquanto Patrocínio alegava que eles eram decorrentes da violência do cativeiro. A questão só foi resolvida com a república, quando os ex-escravos foram anistiados. O embate com

${ }^{15}$ Machado, Humberto F. (2010) "Encontros e desencontros em José do Patrocínio: a luta contra a indenização aos 'Republicanos de 14 de Maio'”. In Ribeiro, Gladys Sabina; Ferreira, Tânia Maria T. Bessone da Cruz (Orgs.) (2010). Linguagens e Práticas da Cidadania no Século XIX, São Paulo: Alameda, p. 301307. 
Quintino Bocaiúva originou-se das disputas eleitorais dentro do Partido republicano da Corte, acentuando-se com os conflitos ocorridos na cidade entre republicanos e Guarda Negra. ${ }^{16}$

Os atritos com Silva Jardim assumiram uma maior dimensão devido ao conflito ocorrido numa Conferência do propagandista republicano na Sociedade Francesa de Ginástica, próximo ao Largo do Rocio, no centro do Rio de Janeiro, em 30 de dezembro de 1888. Durante o evento, membros da Guarda Negra interromperam o seu discurso de forma violenta, invadindo o teatro aos gritos de "viva a monarquia e a Princesa Isabel". O conflito se generalizou ocorrendo, conforme o Cidade do Rio "uma verdadeira batalha campal". O saldo do embate resultou em "feridos, e, talvez, mortos, dentre os da Guarda Negra". De acordo com o jornal, o conflito se desenvolveu em função de "provocações", efetuadas pelos "republicanos escravocratas" contra os libertos. ${ }^{17}$ Já Silva Jardim assinalou que havia um clima propício ao embate entre os republicanos e a associação de libertos, já que o proprietário do Teatro Politeama, local escolhido anteriormente para a realização da Conferência, fora ameaçado por um "grupo de pretos", caso alugasse o espaço para o evento. Assim, a opção por outro local - Sociedade Francesa de Ginásticafoi decorrente desse quadro adverso e seria "mais seguro para os ouvintes, de melhor defesa, em caso de ataque". ${ }^{18}$

Ele responsabilizou o governo pela omissão, em especial João Alfredo, presidente do Conselho de Ministros, acusando-o de ser o presidente honorário da Guarda Negra, e Patrocínio por dar cobertura no Cidade do Rio à associação. Relatou que no meio de sua Conferência "os assistentes foram atacados", e ocorreu uma "Iuta renhida", e se não fosse "a defesa heróica e extraordinária dos corajosos ouvintes que estavam no salão, a minha e as suas pessoas teriam sido vítimas da crueldade dos assaltantes". Destacou que o ambiente foi alvo de pedradas e "constantes tiros", inexistindo condições para a continuidade do evento, assinalou também que muitos feridos eram republicanos, culpando a polícia por omissão que só interveio quando viu "ser grande o estrago nos que

\footnotetext{
${ }^{16}$ Magalhães Jr., Raimundo (1969). A Vida Turbulenta de José do Patrocínio, Rio de Janeiro: Sabiá, p. 253255.

${ }_{17} 3$ de janeiro de 1889. O Largo do Rocio ficava na atual Praça Tiradentes, centro do Rio de Janeiro.

${ }^{18} \mathrm{Jardim}$, Antonio da Silva (1978). Propaganda Republicana (1888-1889), Rio de Janeiro: Fundação Casa de Rui Barbosa/Conselho Federal de Cultura, p. 314-315.
} 
fizera seus". ${ }^{19}$ Conforme Evaristo de Morais, a polícia da Corte acobertou os agressores porque protegia a associação. ${ }^{20}$ Ou seja, a cidade branca via com apreensão a tentativa de participação desses setores marginalizados que viviam na cidade negra. $O$ receio se refletia em preconceito contra os negros, caracterizando uma visão elitista de muitos republicanos.

A Guarda Negra não recebeu a atenção devida pela historiografia. Quando abordada, foi de uma maneira preconceituosa, endossando simplesmente a visão das elites dirigentes contemporâneas, as quais a consideravam como produto das manifestações de desordeiros e desocupados. No entanto, estudos mais recentes demonstram que ela apresentou outras nuances vinculadas ao envolvimento de grupos urbanos na campanha abolicionista. Uma expressão, inclusive, de um período de ebulição que marcou a década de 1880. Cabe assinalar também que ela se inseriu no próprio debate entre republicanos e monarquistas logo após o término da escravidão. ${ }^{21}$ Havia uma forte rejeição por parte dos segmentos populares da Corte, especialmente libertos, aos defensores da República. A população mais humilde, incluindo os libertos, mulatos e brancos pobres, identificavam, como já assinalamos, a Princesa Isabel como a "heroína" e "defensora" dos oprimidos. As idéias republicanas, conforme José Murilo de Carvalho, não tinham grande penetração nos chamados setores populares, sendo que o próprio Imperador detinha grande prestígio entre os segmentos marginalizados. ${ }^{22}$

Exemplo notável do ponto de vista desses setores em relação à monarquia é a atuação do alferes Cândido da Fonseca Galvão, D. Obá II d’África, ou Príncipe Obá, combatente na Guerra do Paraguai, frequentador assíduo do Palácio Imperial da Quinta da Boa Vista, recebido pelo Imperador Pedro II e verdadeiro rei das ruas da Corte. Como Eduardo Silva observa, parcela expressiva dessa população o reverenciava como um verdadeiro príncipe real, sendo que ele, como muitos libertos, via com "azedume" a

\footnotetext{
${ }^{19}$ Ibidem, p.317.

${ }^{20}$ Moraes, Evaristo (1985). Da Monarquia para a República (1870/1889). 2. ed., Brasília: Ed. UNB, p.21.

${ }^{21}$ Gomes, Flávio dos Santos (1991). "No meio das águas turvas (Racismo e cidadania no alvorecer da República: a Guarda Negra na Corte - 1888-1889)" In Estudos Afro-Asiáticos, Rio de Janeiro, n. 21, p. 7596.

${ }^{22}$ Carvalho, José Murilo (1987). Os Bestializados: o Rio de Janeiro e a República que não foi, São Paulo: Cia. das Letras, p. 29-31. Daibert, Robert Júnior (2004). Isabel, a "Redentora" dos escravos. Uma história da Princesa entre olhares negros e brancos (1846-1988), Bauru, SP: EDUSC.
} 
atuação dos republicanos porque considerava a Coroa uma instituição sagrada. ${ }^{23} \mathrm{~A}$ reação desses libertos pode ser atribuída também à possibilidade de uma eventual reescravização, vinculando-a aos projetos de indenização que estavam sendo defendidos por setores republicanos, como já assinalamos. Assim, nada mais natural que a defesa da monarquia e uma oposição aos republicanos.

O Cidade do Rio criticava a visão dos republicanos que, segundo os editoriais, desejavam manter os antigos escravos submissos e afastados dos ventos do progresso. Assim, nada mais natural que eles apoiassem aqueles que empreenderam a abolição, ou seja a monarquia. O jornal não compreendia a "estranheza dos neo-republicanos" em relação aos libertos que desejavam "ver sentada no trono do Brasil aquela que os libertou". ${ }^{24}$ Mais adiante, defendia a Guarda Negra.

É necessário que fique bem claro que essa congregação de homens agradecidos é a conseqüência lógica das bravatas publicadas nos manifestos dos seus exsenhores, e que o fim a que se propuseram, reunindo-se era e é provar ao país que com os seus corpos fazer uma muralha capaz de receber as balas que os neo-republicanos dirijam à sua redentora. É preciso que se saiba bem, que a Guarda Negra se organizou para resistir e não atacar. ${ }^{25}$

A primeira matéria a respeito da Guarda Negra apareceu no Cidade do Rio, em 6 de junho de 1888, através de um convite da "Liga dos Homens de Cor", para que os homens negros fizessem sua inscrição. Ela se apresentava de uma maneira vaga como defensora dos interesses dos libertos. Evidentemente, essa convocação adquiria uma abrangência maior na medida em que há, por um lado, uma campanha pela indenização e, por outro, os pleitos dos abolicionistas em relação à distribuição de terras e educação básica para os ex-escravos. Posteriormente, o jornal publicou que na casa de Émile Rouéde (1848-1908), com a participação de libertos, foi criada a "[...] associação que, com o título de Guarda Negra da Redentora, se dedicasse em corpo e alma e em todos os terrenos à defesa do reinado da excelsa senhora que os fez cidadãos." O periódico anunciou também as diretrizes e estatutos da instituição:

\footnotetext{
${ }^{23}$ Silva, Eduardo (1997). Dom Obá d'África, o príncipe do povo: vida, tempo e pensamento de um homem livre de cor, São Paulo: Cia. das Letras, p.138.

${ }^{24} 5$ de janeiro de 1889.

${ }^{25}$ Ibidem.
} 


\begin{abstract}
1ํ. - Criar uma associação com o fim de opor resistência material a qualquer movimento revolucionário que hostilize a instituição que acabou de libertar o país. 2‥ - Só poderão fazer parte, como seus sócios ativos, os libertos que se comprometerem a obedecer os mandatos de uma Diretoria eleita, por maioria absoluta, em votação que se efetuará em momento oportuno.

3‥ - Poderão ser sócios efetivos unicamente os que considerem o ato memorável do dia 13 de maio, acontecimento digno de admiração geral e não motivo para declarar guerra à humanitária princesa que o realizou.

$4^{\circ}$ - Pedir à Confederação Abolicionista o seu apoio para que esta sociedade se ramifique por todo o império.

5‥ - Pedir à imprensa que participe desse sentimento o seu valioso concurso.

6‥ - E último. Aconselhar por todos os meios possíveis aos libertos do interior que só trabalhem nas fazendas daqueles que não juraram guerrear o $3^{\circ}$ Reinado. ${ }^{26}$
\end{abstract}

A linha de ação estabelecida pelo documento priorizava o apoio incondicional à monarquia e claro a um eventual Terceiro Reinado, sob a égide da Princesa Isabel, a "humanitária princesa". A crítica aos republicanos fica explícita na sua menção a "qualquer movimento revolucionário" contrário à Monarquia, "instituição" que libertou o país da escravidão. O apoio da Confederação Abolicionista e da imprensa permitiria que a associação ampliasse seu campo de atuação para outras partes do Império. $O$ jornal de Patrocínio buscou estabelecer o grau de legitimidade para a Guarda Negra, cujo objetivo era evitar que ela fosse tachada simplesmente como um grupo de capoeiras e capangas que fazia arruaças, conforme acusações dos republicanos.

O Cidade do Rio, referindo-se à Guarda Negra, ressaltava que o seu caráter era de "gratidão", repudiava as insinuações, por parte dos "escravocratas derrotados", de que ela era formada por capoeiras e capangas e que tinha sido fundada, com o apoio do governo, visando a garantir o trono para a Princesa Isabel. O editorial assinalava a existência, na Corte, de homens que

[...] juraram defender a Princesa, custasse-Ihes embora o sangue, [...], essa sociedade defensiva não foi porém, criada pelo governo mas sim pelo coração. É composta exclusivamente por libertos --são os 13 de maio organizados em exército que tomando a gratidão por estandarte, prestaram o juramento sagrado de pagar a liberdade da raça com um ato de amor, dando uma prova ao mundo de que sabem estimar, de que sabem reconhecer, de que sabem amar.

${ }^{26}$ Cidade do Rio (1888). 10 de julho. Émile Rouéde nasceu em Avignon, fixando-se no Rio de Janeiro na década de 1880, atuando nas artes e letras e participando também da campanha abolicionista em órgãos da imprensa, como o jornal de Patrocínio. Miranda, Clícia Maria Augusto (2006). Guarda Negra da Redentora: verso e reverso de uma combativa associação de libertos. Dissertação (Mestrado em História) UERJ, Rio de Janeiro, p. 48. 
A Guarda Negra da Regência não conta no seu número um assalariado, os homens que a compõem [...] vieram do eito, vieram do trabalho, vieram da escravidão. $^{27}$

Patrocínio refutava as acusações dos republicanos, incluindo Silva Jardim, pelos acontecimentos da Sociedade Francesa de Ginástica. Segundo o jornalista, eles promoviam uma verdadeira "campanha de difamação" contra a monarquia e a Princesa Isabel, além das agressões contra os libertos e de uma maneira geral contra os "homens de cor". Segundo o jornalista, os ataques aos libertos pelos republicanos iniciaram-se antes, mencionando um confronto, em 23 de dezembro, domingo anterior à conferência republicana, quando "cinco cidadãos de cor preta" foram atingidos por "pedradas e tiros e repartindo ferimentos e sustos com outros cidadãos que faziam tranquilamente a sua refeição no Hotel Petit-Console", no centro da cidade. ${ }^{28}$

Ele destacou que, nos acontecimentos da Sociedade Francesa de Ginástica, a Guarda Negra revidou às provocações dos republicanos que, no interior do clube, davam "vivas à República", enquanto fora a "multidão continua a bradar: - Viva a monarquia, viva Isabel Redentora", e quando foram disparados tiros, por parte de republicanos, a "multidão armada de pedras" atacou o edifício. Segundo o Cidade do Rio, foram feridos vários "homens de cor" por armas de fogo. A intervenção da polícia acabou com o confronto, mas os distúrbios mantiveram-se durante o resto do dia, como os ataques desferidos contra a redação do jornal republicano O Paíz, cujo redator era Quintino Bocaiúva. ${ }^{29}$ Patrocínio condenou essa ação com 0 argumento de preservação da liberdade de imprensa, embora lamentando que aquele periódico nunca tenha se posicionado na defesa do Cidade do Rio, quando esse foi alvo de "coices nas portas; depois à pedrada", por parte dos republicanos. ${ }^{30}$

A atuação da Guarda Negra, na capital do Império, teve repercussões. Tentativas esparsas de organizações similares ocorreram em São Paulo e na Bahia. Em algumas regiões ocorreram manifestações contrárias, imediatamente aproveitadas pela propaganda republicana. Maria Lúcia Ricci, utilizando textos de jornais favoráveis à

\footnotetext{
2731 de outubro de 1888.

${ }^{28}$ Cidade do Rio (1888), 31 de dezembro.

${ }^{29}$ Ibidem.

${ }^{30}$ Ibidem, 3 de janeiro de 1889.
} 
República, ressaltou os protestos de "[...] negros das outras Províncias [...] indignados contra esta exploração realizada aos de sua raça [...]". Em seguida, a autora comentou que a atuação da Guarda Negra recebeu "[...] a mais enérgica condenação do restante da população negra do país [...]", sem explicitar claramente os detalhes dessa "condenação". Aliás, para a autora a associação era composta por libertos, cuja base era o movimento de capoeiras, inspirados por José do Patrocínio a serviço do trono. ${ }^{31}$

As acusações de vínculos com a capoeiragem aos membros da Guarda Negra era uma estratégia para desqualificar o movimento, visto que os capoeiras eram identificados como desordeiros que provocavam arruaças na cidade do Rio de Janeiro. Pode-se também atribuir esse aspecto aos antecedentes da sua trajetória e as suas relações ambíguas tanto com a campanha abolicionista quanto com a estrutura de poder. Como observa Carlos Eugênio Soares em relação ao assunto, "o tema da abolição cindia ao meio o posicionamento político dos capoeiras", já que uma parcela se alinhava com a própria polícia da Corte, sendo inclusive "parte integrante da estrutura policial", durante o Gabinete Conservador do Barão de Cotegipe, provocando inúmeros conflitos com os abolicionistas, em especial durante o ano de 1887, quando a campanha antiescravista na cidade chegou ao seu apogeu. ${ }^{32}$ Claro que houve uma tentativa de cooptação dos capoeiras durante os Gabinetes Conservadores, incluindo o de João Alfredo.

Mas, por ouro lado, a ação dos capoeiras e a sua arte no manejo de armas, em especial a navalha, nas correrias pelas ruas da cidade provocavam sobressaltos nos governantes e na população de uma maneira geral. As maltas de capoeiras traziam muita insegurança, agravada pelo próprio caráter da sociedade escravista e a especificidade de mobilidade do escravo urbano. A presença marcante de negros nas ruas do Rio de Janeiro reacendia o pavor entre os membros das elites dos fantasmas da Independência

\footnotetext{
${ }^{31}$ Ricci, Maria Lúcia de Souza Rangel (1990). Guarda Negra: Perfil de uma Sociedade em Crise. Campinas, M.L.S.R. Ricci, p. 123-125. Sobre a atuação da Guarda Negra na Bahia, ver Albuquerque, Wlamyra R. de (2009). O jogo da dissimulação: abolição e cidadania negra no Brasil, São Paulo: Cia. Das Letras, 2009, p. $142-172$.

32 Soares, Carlos Eugênio Líbano (1999). A negregada instituição: os capoeiras na Corte Imperial, 18501890, Rio de Janeiro: Access, p. 248-249. Dias, Luiz Sérgio (2001). Quem tem medo da Capoeira? Rio de janeiro, 1890-1904, Rio de Janeiro: Secretaria Municipal das Culturas/Arquivo Geral da Cidade do Rio de Janeiro.
} 
do Haiti ou das revoltas dos Malês na Bahia. ${ }^{33} \mathrm{O}$ mundo da desordem era uma ameaça ao "mundo da ordem" e do "trabalho". No entanto, a capoeira só foi criminalizada com a criação do Código Penal republicano, de 1890, e seus membros perseguidos pelo Chefe de Polícia Sampaio Ferraz, o "Cavanhaque de Aço", e exilados para Fernando de Noronha. ${ }^{34}$ Logo, as críticas à Guarda Negra se vinculavam também à visão estereotipada em relação ao negro, seja escravo ou liberto, por parte das elites republicanas.

Não há dúvida, também, que o Cidade do Rio aproveitava a oportunidade para fazer proselitismo pela monarquia. Em um dos números, na primeira página, bem destacado, publicou um documento cujo conteúdo era um pedido de libertos de Pati de Alferes, na Província do Rio de Janeiro, para que defendesse a Princesa Isabel das calúnias dos "republicanos de 14 de maio". No texto, os signatários agradeciam a "[...] todos os abolicionistas que obtiveram a liberdade para nós e para os nossos filhos [...]". Logo depois, os autores reafirmavam a "lealdade" para com aquela a "[...] quem compete ocupar a elevada posição de Imperatriz [...]". Finalizaram o documento tentando demonstrar que possuíam uma consciência do processo que levou à extinção do cativeiro.

Compreendemos bem que nossa libertação partiu do povo, representado por um punhado de audazes patriotas que quase no fim da sua gloriosa jornada tiveram o apoio eficaz da excelsa princesa e do Gabinete libertador e por isso não levantaremos armas contra os que nos fizeram cidadãos de uma pátria livre e grande. $^{35}$

O documento estava assinado por uma pseudo "comissão de libertos", cuja constituição era formada pelas seguintes pessoas: o primeiro nome era de um branco, Quintiliano Avellar, seguido de dois "pretos", Ambrósio Teixeira e José dos Santos Pereira; dois "pardos", João Gomes Batista e Ricardo de Almeida; um "caboclo" F. de Salles Avellar e, por último, um "disfarçado" (talvez mulato) Sérgio dos Santos. ${ }^{36}$ Em primeiro lugar, o texto possuía uma redação efetuada por pessoas com certo grau de instrução. Torna-se difícil acreditar que os "libertos" soubessem ler dentro do conjunto de

\footnotetext{
${ }^{33}$ Azevedo, Célia Maria Marinho de (1987). Onda Negra Medo Branco. O Negro no Imaginário das Elites séc. XIX, Rio de Janeiro: Paz e Terra.

${ }_{34}^{34}$ Dias, L. S. (2001). Op. Cit., p. 80-81, 126-127.

${ }^{35} 25$ de abril de 1889.

${ }^{36}$ Ibidem.
} 
uma população predominantemente analfabeta. Segundo, como um branco encabeçava um manifesto atribuído a libertos? Terceiro, como já enfatizamos, o jornal de Patrocínio assumiu o papel de defensor da monarquia e, em especial, da Princesa Isabel. Assim era natural que tivesse interesse em divulgar o "manifesto" dos libertos de Pati de Alferes, como os jornais republicanos o faziam com os pronunciamentos contrários.

A partir de meados de 1889, o Cidade do Rio reduziu o seu apoio à Guarda Negra. As intervenções violentas da associação, efetuadas nas comemorações do centenário da Revolução Francesa, em 14 de julho, no centro do Rio de Janeiro, provocaram reações, inclusive de Patrocínio. Os participantes de uma manifestação liderada por entidades republicanas foram atacados por membros da Guarda Negra, ocasionando um conflito na cidade, além de ferimentos entre os oponentes. Patrocínio discorreu sobre os acontecimentos afirmando que a associação desviou-se de seus objetivos preliminares, isto é, opor-se "à onda revolucionária do escravismo". Apelou para que os negros "[...] mais instruídos se consagrem á propaganda humanitária de esclarecer a seus irmãos, evitando agressões, pois a corporação não tinha por missão agredir, mas defender [...]". ${ }^{37}$

Outro aspecto, vinculado a essa mudança de comportamento do jornal, que merece ser ressaltado refere-se à substituição do Gabinete João Alfredo, em 7 de junho de 1889, pelo liberal Afonso Celso Figueiredo, Visconde de Ouro Preto, que governou até o estabelecimento da República. Afonso Celso foi o Ministro da Fazenda quando eclodiu a "Revolta do Vintém", conforme já destacamos. Essa alteração no governo repercutiu também no comportamento de Patrocínio e o início de seu afastamento da monarquia e aproximação com os republicanos. Por outro lado, a Guarda Negra começou a perder o espaço que possuía nos jornais, isto é no Cidade do Rio, enterrada ao som dos clarins da parada militar que derrubou a monarquia. De uma forma melancólica, foi noticiado que um grupo de capoeiras, no dia 22 de novembro de 1889, na Rua do Ouvidor, centro do Rio de Janeiro, dava "vivas à monarquia e morte aos republicanos". 38

Desencadeou-se, no final do ano de 1889, uma perseguição brutal contra os capoeiras e demais vadios da cidade, pelo novo Chefe de Polícia republicano Sampaio

${ }^{37}$ Cidade do Rio (1889). 15 de julho.

${ }^{38} 22$ de novembro de 1889. 
Ferraz. A limpeza da cidade foi efetuada, segundo depoimento do próprio Sampaio Ferraz, através de uma repressão sistemática aos componentes da Guarda Negra e aos demais capoeiras, invadindo as residências: "[...] muitos eram apanhados de surpresa, na hora do descanso, da chegada em casa [...] quando por lá apareciam, já 'estavam no papo' [...] a astúcia policial apanhara cerca de 800 capoeiras, nos primeiros dias [...]". Colocados em navios da Marinha foram exilados para Fernando de Noronha. ${ }^{39}$

A concretização da repressão às classes perigosas, isto é aos indivíduos que viviam no mundo da desordem, foi o mecanismo utilizado para controlar a cidade negra, ameaça constante à cidade branca, européia e civilizada. Assim, o Rio de Janeiro ingressava na fase republicana adequado às normas das elites no que concerne à limpeza das ruas. A eliminação da Guarda Negra e dos demais capoeiras fazia parte da estratégia de civilizar a cidade, depurando-a de suas mazelas e, ao mesmo tempo, prepará-la para o século XX.

\section{Referências}

Abreu, Maurício de Almeida (1988). A evolução urbana do Rio de Janeiro. 2. ed., Rio de Janeiro: IplanRio/Zahar.

Albuquerque, Wlamira (2009). O jogo da dissimulação. Abolição e cidadania negra no Brasil, São Paulo: Companhia das Letras.

Alencastro, Luiz Felipe (1997). "Vida Privada e Ordem Privada no Império". In Alencastro, Luiz Felipe (Org.) (1997). História da Vida Privada no Brasil: Império, São Paulo: Cia. das Letras, v. 2, p. 11-93.

Azevedo, Célia Maria Marinho de (1987). Onda Negra Medo Branco. O Negro no Imaginário das Elites - séc. XIX, Rio de Janeiro: Paz e Terra.

${ }^{39}$ Ferraz, Mário Sampaio (1952). Subsídios para a biografia de Sampaio Ferraz, São Paulo: Rothschild Loureiro, p.40. Bretas, Marcos (1989). A queda do império da navalha e da rasteira, Rio de Janeiro: Casa de Rui Barbosa. 
Barbosa, Marialva (2000). Os Donos do Rio. Imprensa, Poder e Público, Rio de Janeiro: Vício de Leitura.

Bergstresser, Rebecca B. (1973). The Movement for the Abolition of Slavery in Rio de Janeiro, 1880-1889. Tese (Doutorado em História) - Stanford University.

Bretas, Marcos (1989). A queda do império da navalha e da rasteira, Rio de Janeiro: Casa de Rui Barbosa.

Carvalho, José Murilo (1987). Os Bestializados: o Rio de Janeiro e a República que não foi, São Paulo: Cia. das Letras.

Conrad, Robert E. (1978). Os Últimos Anos da Escravatura no Brasil: 1850-1888, Rio de Janeiro: Civilização Brasileira.

Chalhoub, Sidney (1990). Visões da liberdade: uma história das últimas décadas da escravidão na Corte, São Paulo: Cia. das Letras.

Daibert, Robert Júnior (2004). Isabel, a "Redentora" dos escravos. Uma história da Princesa entre olhares negros e brancos (1846-1988), Bauru, SP: EDUSC.

Darnton, Robert (1990). O Beijo de Lamourette. Mídia, Cultura e Revolução, São Paulo: Cia. das Letras.

Dias, Luiz Sérgio (2001). Quem tem medo da Capoeira? Rio de janeiro, 1890-1904, Rio de Janeiro: Secretaria Municipal das Culturas/Arquivo Geral da Cidade do Rio de Janeiro.

Edmundo, Luiz (1957). O Rio de Janeiro do Meu Tempo. 2. ed., Rio de Janeiro: Conquista. 5 v.

Ferraz, Mário Sampaio (1952). Subsídios para a biografia de Sampaio Ferraz, São Paulo: Rothschild Loureiro.

Gomes, Flávio dos Santos (1991). "No meio de águas turvas (Racismo e Cidadania no alvorecer da República: a Guarda Negra na Corte). (1888-1889)". In Estudos AfroAsiáticos, Rio de Janeiro, n. 21, p. 75-96.

Goulart, Paulo Cezar Alves (1987). "A venda de jornais no século XIX". In Leitura, São Paulo, v. 5, n. 57.

Graham, Sandra L. (1991). "O motim do Vintém e a cultura política do Rio de Janeiro em 1880". In Revista Brasileira de História, São Paulo, v.10, n. 20, p. 211-232.

Jardim, Antonio da Silva (1978). Propaganda Republicana (1888-1889), Rio de Janeiro: Fundação Casa de Rui Barbosa/Conselho Federal de Cultura. 
Karasch, Mary C. (2000). A vida dos escravos no Rio de Janeiro (1808-1850), São Paulo: Cia. das Letras.

Koseritz, Carl Von (1980). Imagens do Brasil, São Paulo: EDUSP; Belo Horizonte: Itatiaia.

Machado, Humberto F. (1992) "A Guarda Negra no Contexto Urbano do Rio de Janeiro", In Anais da XII Reunião da Sociedade Brasileira de Pesquisa Histórica, Porto Alegre: SBPH.

(1998). "O Abolicionismo 'ganha as ruas' no Rio de Janeiro". In Revista da Sociedade Brasileira de Pesquisa Histórica, Curitiba, n. 4, p. 71-76.

(2010). "Encontros e desencontros em José do Patrocínio: a luta contra a indenização aos 'Republicanos de 14 de Maio'”. In Ribeiro, Gladys Sabina; Ferreira, Tânia Maria T. Bessone da Cruz (Orgs.) (2010). Linguagens e Práticas da Cidadania no Século $X I X$, São Paulo: Alameda.

Machado, Maria Helena (1994). O Plano e o pânico: os movimentos sociais na década da abolição, Rio de Janeiro: EDUFRJ; São Paulo: EDUSP.

Magalhães Jr., Raimundo (1969). A Vida Turbulenta de José do Patrocínio, Rio de Janeiro: Sabiá.

Miranda, Clícia Maria Augusto (2006). Guarda Negra da Redentora: verso e reverso de uma combativa associação de libertos. Dissertação (Mestrado em História) - UERJ, Rio de Janeiro.

Moraes, Evaristo (1985). Da Monarquia para a República (1870/1889), 2. ed., Brasília: Ed. UNB.

Nabuco, Joaquim (1949). Obras completas de Joaquim Nabuco: O Abolicionismo. Conferências e Discursos Abolicionistas, São Paulo: Progresso Editorial, v. 7.

Ricci, Maria Lúcia de Souza Rangel (1990). Guarda Negra: Perfil de uma Sociedade em Crise, Campinas: M.L.S.R. Ricci.

Silva, Eduardo (1997). Dom Obá d'África, o príncipe do povo: vida, tempo e pensamento de um homem livre de cor, São Paulo: Cia. das Letras.

Soares, Carlos Eugênio Líbano (1999). A negregada instituição: os capoeiras na Corte Imperial, 1850-1890, Rio de Janeiro: Access. 


\section{Jornais}

Cidade do Rio (1888), 10 de julho.

Cidade do Rio (1888), 31 de outubro.

Cidade do Rio (1888), 31 de dezembro.

Cidade do Rio (1889), 03 de janeiro.

Cidade do Rio (1889), 05 de janeiro.

Cidade do Rio (1889), 25 de abril.

Cidade do Rio (1889), 15 de julho.

Gazeta da Tarde (1887), 8 de agosto.

Recebido para publicação em julho de 2013.

Aprovado para publicação em agosto de 2013. 